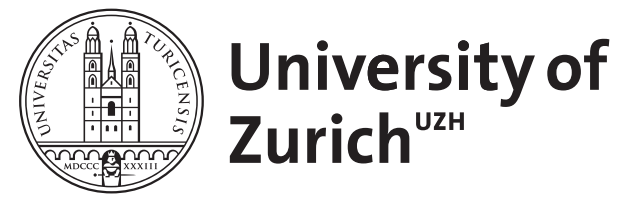

Zurich Open Repository and Archive

University of Zurich

University Library

Strickhofstrasse 39

CH-8057 Zurich

www.zora.uzh.ch

Year: 2021

\title{
Government Responses on Corona and Contracts in Europe: A Compilation of Extraordinary Measures in Times of Crisis
}

\author{
Jentsch, Valentin
}

Posted at the Zurich Open Repository and Archive, University of Zurich

ZORA URL: https://doi.org/10.5167/uzh-211779

Journal Article

Published Version

Originally published at:

Jentsch, Valentin (2021). Government Responses on Corona and Contracts in Europe: A Compilation of Extraordinary Measures in Times of Crisis. European Business Law Review, 32(6):1067-1091. 


\title{
Government Responses on Corona and Contracts in Europe: A Compilation of Extraordinary Measures in Times of Crisis
}

\author{
VALENTIN JENTSCH*
}

\begin{abstract}
In March 2020, the new coronavirus (Covid-19) outbreak, which was eventually declared a pandemic by the World Health Organization, changed everyday life all over Europe from one day to another. Under those extraordinary circumstances, a wide range of issues concerning the law of contracts are becoming particularly important. In the early stages of the pandemic, during lockdowns and a subsequent reopening of the economy, many European countries have implemented significant and unprecedented measures in response to the current crisis. Against this backdrop, the more fundamental question arises whether and to what extent we need an extraordinary law of contracts in times of pandemic. Drawing on five important civil law jurisdictions (Germany, Austria, Switzerland, France, Italy), the paper provides for an analysis and discussion of various extraordinary measures taken by European governments and puts these measures into perspective. A functional and comparative approach is used to elaborate on how contract law should respond to the current crisis.
\end{abstract}

\section{Keywords}

Coronavirus (Covid-19) pandemic, commercial contracts, consumer contracts, employment contracts, lease contracts

\section{Introduction}

The rapidly spreading coronavirus (Covid-19) outbreak, which was declared a pandemic by the World Health Organization on 11 March 2020, all of a sudden changed everyday life all over Europe and around the world from one day to another. Airlines were cancelling flights, companies were shut down and consumers were rapidly changing their buying behaviour. In addition, many European countries enacted emergency decrees, according to which national borders were closed, cities were sealed off, major events involving more than a certain number of people were banned and

\footnotetext{
* Dr. iur., LL.M., Attorney at law. Research Associate at the University of Zurich, Visiting Fellow at the Max Planck Institute for Tax Law and Public Finance in Munich, Germany. 
teaching in schools and universities was suspended - at least for some time. There is no need to say that this situation has caused considerable difficulties for all participants in the economy, business enterprises and customers alike.

Under those extraordinary circumstances, a wide range of issues concerning the law of contracts are becoming particularly important, such as whether existing contracts are still valid and binding, and thus must be adhered to, or whether performance may be suspended or its acceptance refused. ${ }^{1}$ From a conceptual perspective, these issues may be reframed on the basis of two general principles of law. The principle of pacta sunt servanda requires that both or all parties are expected to meet their contractual obligations, thereby ensuring efficacy and efficiency of the system of private ordering. ${ }^{2}$ In certain exceptional situations, however, where performance is no longer possible or circumstances change fundamentally after an agreed transaction, contractual performance may be excused and contractual obligations adapted or terminated. This is where the clausula rebus sic stantibus, together with concepts such

${ }^{1}$ From an international perspective, see Franz T. Schwarz et al., Introduction in Franz T. Schwarz et al. (eds.), Contractual Performance and COVID-19: An In-Depth Comparative Law Analysis (28 Apr. 2020), at paras 1-3. On the Principles for the Covid-19 Crisis of the European Law Institute, see Gerhard Wagner, Corona Law 28 Zeitschrift für Europäisches Privatrecht 531 (2020). For a first interpretative note under Austrian law, see Markus Uitz \& Hemma Parsché, Vertragsverstösse aufgrund COVID-19 1 COVID-19 und Recht [no. 1] (2020). On contract adaption under Swiss law, see Andrea Haefeli et al., Anpassung privatrechtlicher Verträge infolge von COVID-19 in COVID-19: Ein Panorama der Rechtsfragen zur Corona-Krise, 1-38 (Basel: Helbing Lichtenhahn, 2020). For a preliminary assessement under French law, see Ludovic Landivaux, Contrats et coronavirus : un cas de force majeure ? Ça dépend ..., Dalloz actualité (20 Mar. 2020); Constance Verroust-Valliot \& Serge Pelletier, L'impact du covid-19 sur les contrats de droit privé, Dalloz actualité (9 Jun. 2020). On the eternal conflict between the principles of pacta sunt servanda and rebus sic stantibus from an Italian perspective, see Antonia S. M. Roseti, Il COVID-19 riaccende l'eterno conflitto tra il principio pacta sunt servanda e il principio rebus sic stantibus, Diritto del Risparmio (17 Aug. 2020).

${ }^{2}$ For a comprehensive study on this principle in German private law, see Marc-Philippe Weller, Die Vertragstreue: Vertragsbindung, Naturalerfüllungsgrundsatz, Leistungstreue (Tuebingen: Mohr Siebeck, 2009). From an Austrian perspective, see Jürgen Noll, Pacta sunt servanda \& clausula rebus sic stantibus: Der Wert der Vertragstreue 64 Österreichisches Anwaltsblatt 260 (2002). From the perspective of Swiss law in general, see Bernd Stauder, Pacta sunt servanda et le droit de repentir des consommateurs 104 La Semaine Judicaire 481 (1982); Daniel Leu, Vertragstreue in Zeiten des Wandels: Die clausula rebus sic stantibus und das Kriterium der Vorhersehbarkeit in Daniel Dédeyan et al. (eds.), Vertrauen, Vertrag, Verantwortung, 21-44 (Zurich: Schulthess, 2007); Pascal Hachem, Die Konturen des Prinzips Pacta Sunt Servanda in Andrea Büchler \& Markus Müller-Chen (eds.), Private Law: national, global, comparative, $647-667$ (Berne: Stämpfli, 2011); Arnaud Campi, Pacta sunt servanda ... aut riscindenda ? L'évolution de notre droit des obligations face au dilemme des conventions lésionnaires in Olivier Hari (ed.), Protection de certains groupements de personnes ou de parties faibles versus libéralisme économique : quo vadis ?, 21-44 (Zurich: Schulthess, 2016). With regard to mergers and acquisitions under Swiss law, see Heinz Schärer \& Balz Gross, Pacta sunt servanda - von der Realerfüllung des Unternehmenskaufvertrags und deren prozessualer Durchsetzung in Rudolf Tschäni (ed.), Mergers \& Acquisitions XVI, 115-171 (Zurich: Schulthess, 2014). From a French perspective, see Johannes Bärmann, Pacta sunt servanda : Considérations sur l'histoire du contrat consensuel 13 Revue internationale de droit comparé 18 (1961). From an Italian perspective, see Giovanni Pascuzzi, Pacta sunt servanda: Giornale didattico e selezione di giurisprudenza sul diritto dei contratti (Bologna: Zanichelli, 2006). 
as force majeure or hardship, comes into play. ${ }^{3}$ These general legal institutions form the foundation for how the law deals with contracts during the coronavirus pandemic. The requirements and consequences of these general legal institutions and their scope and application by legislators and judges are, however, not the focus of this paper. ${ }^{4}$

\footnotetext{
${ }^{3}$ For a historial and comparative account, see Reinhard Zimmermann, 'Heard melodies are sweet, but those unheard are sweeter... ': Condicio tacita, implied condition und die Fortbildung des europäischen Vertragsrechts 193 Archiv für die civilistische Praxis 121 (1993); Andreas Thier, Legal History in Ewoud Hondius \& Christoph Grigoleit (eds.), Unexpected Circumstances in European Contract Law, 15-32 (Cambridge: Cambridge, 2011). For a doctrinal analysis from a German perspective, see Ralf Köbler, Die 'clausula rebus sic stantibus' als allgemeiner Rechtsgrundsatz (Tuebingen: Mohr Siebeck, 1991). For a historical analysis from a German perspective, see Georg Gieg, Clausula rebuc sic stantibus und Geschäftsgrundlage: Ein Beitrag zur Dogmengeschichte (Dueren: Shaker, 1994). From a historical analysis from an Austrian perspective, see Caroline Mokrejs, Die clausula rebus sic stantibus - die antiken Quellen und ihre moderne Rezeption (Vienna: Universität Wien, 2011). From a Swiss perspective, see Pierre Tercier, La 'clausula rebus sic stantibus' en droit suisse des obligations 105 Journal des Tribunaux 194 (1979); Martin Burkhardt, Vertragsanpassung bei veränderten Umständen in der Praxis des schweizerischen Privatrechts: Vertragsgestaltung, Schiedsgerichtspraxis und Praxis des Bundesgerichts (Bern: Haupt, 1997); Pascal Pichonnaz, La modification des circonstances et l'adaptation du contrat in Pascal Pichonnaz \& Franz Werro (eds.), La pratique contractuelle 2, 21-54 (Zurich: Schulthess, 2011); Ernst A. Kramer, Neues zur clausula rebus sic stantibus 110 Schweizerische Juristen-Zeitung 273 (2014); Benjamin V. Enz, Clausula rebus sic stantibus - Insbesondere im Spiegel der Rechtsprechung (Zurich: Schulthess, 2018). On the occurrence and rejection of the principle rebus sic stantibus under French law, see Louis Thibierge, Le contrat face à l'imprévu (Paris: Economica, 2011), at paras 194-215. On the concept of causa del contratto under Italian law, see Guido Alpa, L'uso giurisprudenziale della causa del contratto 11 La nuova giurisprudenza civile commentata 1 (1995).

${ }^{4}$ For a functional and comparative approach, see Valentin Jentsch, Contractual Performance, Breach of Contract and Contractual Obligations in Times of Crisis: On the Need for Unification and Codification in European Contract Law 29 European Review of Private Law (2021) [forthcoming]. From a German perspective, see Stephan Lorenz, Allgemeines Leistungsstörungsrecht und Veranstaltungsrecht in Hubert Schmidt, COVID-19: Rechtsfragen zur Corona-Krise, 1-28 (2nd ed., Munich: Beck, 2020), at § 1 paras 2-32, 51-78; Isabell Weaver, Störung der Lieferkette durch Covid-19 - Force Majeure? Es kommt darauf an! 9 Zeitschrift für Vertriebsrecht 159 (2020); Marc-Philippe Weller et al., Virulente Leistungsstörungen - Auswirkungen der Corona-Krise auf die Vertragsdurchführung 73 Neue Juristische Wochenschrift 1017 (2020). From an Austrian perspective, see Burghard Piltz, Covid-19 bedingte Lieferstörungen 20 Internationales Handelsrecht 133 (2020); Karl-Heinz Thume, Covid-19 und Vertriebsverträge 20 Internationales Handelsrecht 163 (2020); Alexander Wilfinger, Behördliche Verbote und Vertrag 75 Österreichische Juristen-Zeitung 437 (2020). From a Swiss perspective, see Benjamin V. Enz, Risikozuordnung in Verträgen und die COVID-19 Situation: Teil 1 - Anwendungsbereich der clausula rebus sic stantibus, der Unmöglichkeit nach Art. 119 OR und der Kündigung aus wichtigem Grund, Jusletter (18 May 2020); Benjamin V. Enz \& Sarah Mor, Risikozuordnung in Verträgen und die COVID19 Situation: Teil 2 - Problemstellungen der COVID-19 Situation im Werkvertragsrecht, Jusletter (10 Aug. 2020); Valentin Jentsch, The Law of Contracts in the Age of the Coronavirus Pandmic: Is the Statutory Risk Allocation pursuant to the Swiss Code of Obligations Still Adequate?, Jusletter (7 Sep. 2020). From a French perspective, Mustapha Mekki, De l'urgence à l'imprévue du Covid-19 : quelle boîte à outils contractuels? 7 Actualité Juridique Contrat 164 (2020); Louis Vogel \& Joseph Vogel, Possibilités, limites et exclusions du recours à l'imprévisioni dans la crise du Covid-19 7 Actualité Juridique Contrat 275 (2020). From an Italian perspective, see Stefano Verzani, Gli effetti, sui contratti in corso, dell'emergenza sanitaria legata al COVID-19 7 Giustizia Civile [speciale no. 1] 213 (2020); Fulvio Gigliotti, Considerazioni in teme di impossibilità sopravvenuta, per emergenza epidemiologica,
} 
This paper focusses on the extraordinary measures taken by governments and their administrations in response to the current crisis, notably with a view to Europe.

Many European countries have implemented significant and unprecedented measures during the coronavirus pandemic, both in the context of a lockdown period and after the subsequent reopening of the economy, especially in the early stages of the pandemic. ${ }^{5}$ Initially, these measures were mainly aimed at preventing or at least slowing down the spread of the virus. This includes in particular a ban of events involving more than a certain number of people, the protection of the most vulnerable individuals, the closure of national borders and the enactment of border controls as well as the closure of bars, shops and other gathering venues. In a next step, the main aim was to cure the economic consequences caused by the coronavirus and various containment measures taken by the government. The bouquet of these measures is as varied as the crisis itself, ranging from providing business enterprises with liquidity, protecting special needs of customers and, in some form or another, guarantee jobs and the income of workers. From a contract law perspective, it is exactly this variety of measures that is most relevant for the scope and application of general legal institutions such as the principle of pacta sunt servanda, the clausula rebus sic stantibus and concepts such as force majeure or hardship. Therefore, the measures taken by European governments in spring and summer 2020 are the subject of this paper, presented as a snapshot across time and space.

Against this backdrop, the more fundamental question arises whether and to what extent we need an extraordinary law of contracts in times of pandemic. ${ }^{6}$ This question

di prestazioni dello spettacolo e assimilate 7 Giustizia Civile [speciale no. 1] 237 (2020); Rosario Franco, Emergenza, diritto delle obbligazioni, umanità 7 Giustizia Civile [speciale no. 3] 359 (2020).

5 On restrictions of free movement and contact in Germany, see Annette Guckelberger, Ausgangsbeschränkungen und Kontaktverbote anlässlich der Corona-Pandemie 39 Neue Zeitschrift für Verwaltungsrecht 607 (2020). On lockdown measures in Austria, see Günther Leissler, EpidemieG und COVID-19-MassnahmenG: Massnahmen und Entschädigungen 31 Fachzeitschrift für Wirtschaftsrecht 286 (2020); Robert Keisler \& Sylvia Hummelbrunner, Epidemierecht in Reinhard Resch (ed.), Das Corona-Handbuch: Österreichs Rechtspraxis zur aktuellen Lage, 1-34 (Vienna: Manz, 2020). On reopening measures in Austria, see Dietmar Dokalik, Die gesetzlichen Begleitmassnahmen zum COVID19-Shutdown im Wirtschaftsrecht 4 Der Jahres-Abschluss 64 (2020). For a critical assessment of all these measures under Swiss public law, see Benjamin Märkli, Die 'Corona-Verordnung' des Bundesrats vom 28. Februar 2020, Jusletter (9 Mar. 2020); Giovanni Biaggini, 'Notrecht' in Zeiten des Coronavirus - Eine Kritik der jüngsten Praxis des Bundesrats zu Art. 185 Abs. 3 BV 121 Schweizerisches Zentralblatt für Staats- und Verwaltungsrecht 239 (2020); Andreas Kley, 'Ausserordentliche Situationen verlangen nach ausserordentlichen Lösungen' - Ein staatsrechtliches Lehrstück zu Art. 7 EpG und Art. 185 Abs. $3 B V 121$ Schweizerisches Zentralblatt für Staats- und Verwaltungsrecht 268 (2020). For an overview of these measures in France, see Épidémie de Covid-19 : présentation d'un projet de loi d'urgence 196 Recueil Dalloz 604 (2020); Épidémie de Covid-19 (conséquences) : présentation d'un projet de loi 196 Recueil Dalloz 987 (2020). From an Italian perspective, see Luca Guerrini, Coronavirus, legislazione emergenziale, e contratto: una fotografia 7 Giustizia Civile [speciale no. 3] 345 (2020).

${ }^{6}$ From a German perspective, see Thomas Liebscher et al., Recht der Leistungsstörungen im Lichte der COVID-19-Pandemie 39 Zeitschrift für Wirtschaftsrecht 852 (2020); Volker Römermann (ed.), Verträge (neu) verhandeln in Zeiten von Corona (Munich: Beck, 2020). From an Austrian perspective, see Thomas Rabl, COVID-19-Risiko im Vertrag: Zu 'höherer Gewalt', Geschäftsgrundlage und dem 'eifrigen' Gesetzgeber 1 COVID-19 und Recht [no. 36] (2020); Clemens Grünzweig, Vertragsbindung 
cannot be answered in the abstract and without close connection to the existing rules and regulations, namely general legal institutions such as subsequent impossibility or delay of performance and adaption or termination of contracts. Only if these instruments provided by legislators and decided by judges do not work or do not work properly, state intervention and additional extraordinary measures under the auspices of governments and their administrations will be necessary. However, it is still too early to answer this question. The provision of and decision on these general legal institutions by both legislators and judges in the age of the pandemic can only be assessed and evaluated retrospectively. Time will tell what works and what does not. But what can already be tackled now, and that is the focus of this paper, consists of an analysis and discussion of the extraordinary measures taken by certain European governments, combined with a legal impact assessment. This is important in order to take appropriate countermeasures in good time, if necessary.

Drawing on five important civil law jurisdictions (Germany, Austria, Switzerland, France, Italy), the paper provides for an analysis and discussion of various extraordinary measures taken by European governments and puts these measures into perspective. These measures are not only analysed and discussed with regard to business enterprises, customers and other contracting parties, but also and in particular in relation to commercial, consumer, employment and lease contracts. A functional and comparative approach is used to elaborate on how contract law should respond to the current crisis.

\section{General Measures for Business Enterprises: Responses for Commercial Contracts}

The extraordinary measures for business enterprises included financial support and certain legislative changes affecting business enterprises in general and commercial contracts in particular. ${ }^{7}$ The financial support mainly intended to ensure liquidity of

\footnotetext{
in Zeiten von Covid-19 1 COVID-19 und Recht [no. 51] (2020). From a Swiss perspective, see Pascal Pichonnaz, Un droit contractuel extraordinaire ou comment régler les problèmes contractuels en temps de pandémie 139 Zeitschrift für Schweizerisches Recht [Sondernummer] 137 (2020). From a French perspective, see Cyril Grimaldi, Quelle jurisprudence demain pour l'épidémie de Covid-19 en droit des contrats ? 196 Recueil Dalloz 827 (2020). From an Italian perspective, see Aldo A. Dolmetta, Il problema della rinegoziazione (ai tempi del coronvirus) 7 Giustizia Civile [speciale no. 3] 319 (2020).

${ }^{7}$ For Germany, see André Janssen \& Christian Johannes Wahnschaffe, Der internationale Warenkauf in Zeiten der Pandemie 31 Europäische Zeitschrift für Wirtschaftsrecht 410 (2020); Marius Mann et al. (eds.), Vertrieb von Waren und Dienstleistungen in Zeiten von Corona - Ein Rechtsleitfaden zu COVID-19-bedingten Vertragsstörungen (Munich: Beck, 2020); Sabine Otte-Gräbener, Auswirkungen der COVID-19-Pandemie auf Lieferverträge 12 Gesellschafts- und Wirtschaftsrecht 147 (2020); Jörg Rehder \& Dominik Schmidt, Auswirkungen der COVID-19-Pandemie auf die Vertragsabwicklungen unter Betrachtung des deutschen und US-amerikanischen Leistungsstörungsrechts 1 COVID-19 und Recht 459 (2020); Volker Römermann (ed.), Leitfaden für Unternehmen in der Covid-19 Pandemie Insolvenzrecht, Gesellschaftsrecht, Arbeitsrecht, Steuerrecht (Munich: Beck, 2020); Volker Römermann (ed.), Erste Hilfe für Selbständige und Unternehmer in Zeiten von Corona - Mit allen relevanten
} 
funds, but partly also replaced lost profits, for instance in the form of tax deferrals. The Member States of the European Union have themselves provided massive aid packages for their companies. In addition, the European Union itself has also adopted a temporary framework for State aid. This means that several pots with State aid were available to such companies not only in their respective countries, but also at the supranational level. As many companies were likely to meet the requirements of several aid packages and therefore could benefit from them in several ways, it might well be possible that some companies claimed more State aid than they actually needed, which is certainly not unproblematic. The legislative changes included temporary modifications or suspensions of certain provisions from insolvency law in order to avoid a major wave of bankruptcies because of illiquidity due to a lack of sales and profits, but also a standstill of procedural and/or substantive time limits. Some Member States have also suspended the effects of certain contractual remedies aimed at sanctioning non-performance. Other Member States even went a step further, enacting an overriding provision, according to which compliance with governmentissued containment measures shall always be considered when interpreting debtor's liability and contractual remedies for non-performance.

In Germany, both government and legislator have prompted various rescue measures to support business enterprises. The main financial measures adopted in Germany include liquidity support by the German state-owned development bank, Kreditanstalt für Wiederaufbau (KfW), the establishment of the economic stabilisation fund by the German Federal Government and legislative changes to mitigate the consequences of the coronavirus pandemic with respect to specific contract, corporate, insolvency and criminal law matters. Under various loan schemes, KfW provided an unlimited amount of liquidity support available to all companies ranging from the smallest businesses to large publicly-listed multinational corporations. ${ }^{8}$ The German federal budget guaranteed KfW a financial framework of around 460 billion euro,

Themen wie u.a.: Insolvenzantrag, Mietverhältnis, Darlehen (Munich: Beck, 2020); Karl-Heinz Thume, Auswirkungen der COVID-19-Pandemie auf nationale und grenzüberschreitende Vertriebsverträge 75 Betriebs-Berater 1419 (2020); Eric Wagner et al., Auswirkungen von COVID-19 auf Lieferverträge 75 Betriebs-Berater 845 (2020); Johann Wagner \& Enrico Rarinato, COVID-19 und Steuerrecht - Die wichtigsten Entwicklungen für Unternehmen 1 COVID-19 und Recht 286 (2020). For Austria, see Thomas Angermair et al., COVID-19-Gesetze: Ausgewählte für Unternehmen relevante Fragen 152 Österreichische Notariatszeitung 121 (2020). For Switzerland, see Daniel Staehelin \& Lukas Bopp, Insolvenzrechtliche Massnahmen zur Bewältigung der Coronakrise in COVID-19: Ein Panorama der Rechtsfragen zur Corona-Krise, 513-538 (Basel: Helbing Lichtenhahn, 2020); Benedict F. Christ et al., Hilfsmassnahmen für Unternehmen in COVID-19: Ein Panorama der Rechtsfragen zur Corona-Krise, 539-566 (Basel: Helbing Lichtenhahn, 2020). For France, see Julia Heinich, L'incidence de l'épidémie de coronavirus sur les contrats d'affaires : de la force majeure à l'imprévision 196 Recueil Dalloz 611 (2020); Roland Ziadé \& Claudia Cavicchioli, L'impact du Covid-19 sur les contrats commerciaux 7 Actualité Juridique Contrat 176 (2020). For Italy, see Aurelio Gentili, Una proposta sui contratti d'impresa al tempo del coronavirus 7 Giustizia Civile [speciale no. 3] 383 (2020).

${ }^{8}$ See Bundesregelung Bürgschaften 2020, Bundesministerium für Wirtschaft und Energie (20 Mar. 2020); Bundesregelung Kleinbeihilfen 2020, Bundesministerium für Wirtschaft und Energie (26 Mar. 2020) - Erste Änderung (11 Apr. 2020), Zweite Änderung (3 Aug. 2020); Bundesregelung Beihilfen für niedrigverzinsliche Darlehen 2020, Bundesministerium für Wirtschaft und Energie (16 Apr. 2020) 
which, if necessary, could be increased by up to 93 billion euro. The economic stabilisation fund was intended to reduce the damage caused to the German economy by stabilizing companies whose existence is of significant importance for the economy in Germany and its labour market. ${ }^{9}$ The changes introduced by the emergency legislation of 27 March 2020, which were particularly important for business enterprises, included a suspension of the obligation to file for insolvency, a relief from liability for managing directors and protection from insolvency clawback. ${ }^{10}$ In addition, this legislation also introduced a moratorium for the performance of certain long-term contracts for small business enterprises. ${ }^{11}$ This moratorium related to commercial contracts considered to be important for the continuation of business operations such as contracts for electricity, gas and telephone and internet connections. The scope of application of these regulations was thus rather narrow.

In Austria, the government and the parliament have put together a large package of financial support, which was supposed to address the economic consequences of the coronavirus crisis. The financial support provided to business enterprises included in particular non-repayable grants as well as loan subsidies and guarantees. For this purpose, government and parliament have set up different support schemes and funding pools. On 15 March 2020, the Austrian Parliament set up a Covid-19 crisis fund, which was initially endowed with up to 4 billion euro. ${ }^{12}$ Only three day later, on 18 March 2020, the Austrian Federal Government announced an increase of the Covid19 crisis fund to 38 billion euro. On 21 March 2020, the Austrian Parliament set up an additional hardship fund in the amount of 2 billion euro as a first aid measure for the personal standard of living of small and micro-entrepreneurs. ${ }^{13}$ On 4 April 2020, the Austrian Parliament increased the endowment of the Covid-19 crisis fund from 4 to 28 billion euro, while the remaining 10 billion euro derived from tax deferrals, governed by the Austrian Federal Fiscal Code. ${ }^{14}$ These support schemes and funding pools served as basis for government guarantees of 80 percent for bridging loans. In addition, tax and duty deferrals could be obtained from both tax office and social security institutions. Moreover, government and parliament have made available 15

- Neufassung (4 Aug. 2020). See also Gesetz über die Kreditanstalt für Wiederaufbau (5 Nov. 1948), WiGB1, 123 - Neufassung (23 Jun. 1969), BGB1 I, 573.

9 See Gesetz zur Errichtung eines Wirtschaftsstabilisierungsfonds (27 Mar. 2020), BGB1 I, 543.

10 See Art. 1 of Gesetz zur Abmilderung der Folgen der COVID-19-Pandemie im Zivil-, Insolvenzund Strafverfahrensrecht (27 Mar. 2020), BGB1 I, 569 - Gesetz zur vorübergehenden Aussetzung der Insolvenzantragspflicht und zur Begrenzung der Organhaftung bei einer durch die COVID-19-Pandemie bedingten Insolvenz.

${ }^{11}$ See Art. 5 of Gesetz zur Abmilderung der Folgen der COVID-19-Pandemie im Zivil-, Insolvenzund Strafverfahrensrecht (27 Mar. 2020), BGB1 I, 569 - Art. $240 \S 1$ 1(2) of Einführungsgesetz zum Bürgerlichen Gesetzbuche.

12 See Art. 1 of COVID-19 Gesetz (15 Mar. 2020), BGB1 I, no. 12 - Bundesgesetz über die Errichtung des COVID-19-Kriesenbewältigungsfonds.

13 See Art. 15 of 2. COVID-19-Gesetz (21 Mar. 2020), BGBl I, no. 16 - Bundesgesetz über die Errichtung eines Härtefallfonds.

${ }^{14}$ See Art. 29 of 3. COVID-19-Gesetz (4 Apr. 2020), BGB1 I, no. 23 - Änderung des Bundesgesetzes über die Errichtung des COVID-19-Kriesenbewältigungsfonds. 
billion euro in addition to previous instruments, namely by the establishment of the corona relief fund to cover liquidity requirements (credit guarantees) and later also overheads (fixed cost allowances). ${ }^{15}$ Additional measures to postpone possible insolvencies of business enterprises, which were adopted by the Austrian Parliament, included an extension of the period for the debtor's own insolvency petition from 60 to 120 days and a suspension of the debtor's obligation to file for insolvency due to over-indebtedness, if such over-indebtedness occurred between 1 March and 30 June 2020. ${ }^{16}$ The interruption of time limits in civil and administrative proceedings and the suspension of substantive time limits, in particular the statute of limitations, were particularly relevant for commercial contracts. ${ }^{17}$

In Switzerland, the Swiss Federal Council has approved a comprehensive package of measures totalling over 60 billion Swiss Francs to cushion the economic consequences of the spread of the coronavirus. The aim of the measures, which were aimed at various target groups, was to avoid redundancies, maintain employment, safeguard wages and provide support for the self-employed. A central piece of these measures for business enterprises were bridging credits (Covid-19 credits), which were designed to provide companies in Switzerland with liquidity relief totalling 40 billion Swiss Francs in order to help with the economic consequences of the coronavirus. ${ }^{18}$ Other industry-specific measures provided financial support to culture, sports and tourism. ${ }^{19}$ In addition, the Swiss Federal Council ordered a temporary standstill in debt collection on 18 March 2020, which - not only, but in particular - applied to business enterprises. ${ }^{20}$ From 19 March to and including 4 April 2020, no enforcement proceedings on debt collection could have been carried out against business enterprises

15 See Art. 4 of COVID-19 Gesetz (15 Mar. 2020), BGB1 I, no. 12 - Änderung des Bundesgesetzes über die Einrichtung einer Abbaubeteiligungsaktiengesellschaft des Bundes; Art. 26 of 3. COVID19-Gesetz (4 Apr. 2020), BGB1 I, no. 23 - Änderung des Bundesgesetzes über die Einrichtung einer Abbaubeteiligungsaktiengesellschaft des Bundes.

${ }^{16}$ See Art. 37 of 4. COVID-19-Gesetz (4 Apr. 2020), BGBl I, no. $24-\S \S 7$ and 9 of 2. COVID19-Justiz-Begleitgesetz.

${ }_{17}$ For civil proceedings, see Art. 21 of 2. COVID-19-Gesetz (21 Mar. 2020), BGB1 I, no. $16-\S \S$ 1 and 2 of 1. COVID-19-Justiz-Begleitgesetz; Art. 32 of 4. COVID-19-Gesetz (4 Apr. 2020), BGB1 I, no. 24 - Änderung des 1. COVID-19-Justiz-Begleitgesetzes. For administrative proceedings, see Art. 16 of 2. COVID-19-Gesetz (21 Mar. 2020), BGB1 I, no. $16-\S \S 1$ and 2 of Verwaltungsrechtliches COVID-19-Begleitgesetz; Art. 1 of 4. COVID-19-Gesetz (4 Apr. 2020), BGB1 I, no. 24 - Änderung des Verwaltungsrechtlichen COVID-19-Begleitgesetzes.

18 See Verordnung zur Gewährung von Krediten und Solidarbürgschaften in Folge des Coronavirus (25 Mar. 2020), AS 2020, 1077.

19 For culture, see Verordnung über die Abfederung der wirtschaftlichen Auswirkungen des Coronavirus (COVID-19) im Kultursektor (20 Mar. 2020), AS 2020, 855. For sports, see Verordnung über Begleitmassnahmen im Sportbereich zur Abfederung der Folgen von Massnahmen des Bundes zur Bekämpfung des Covonavirus (20 Mar. 2020), AS 2020, 851; Verordnung über die Förderung von Sport und Bewegung (23 May 2012), AS 2012, 3967 - Änderung (20 May 2020), AS 2020, 1757. For tourism, see Art. 4 of Verordnung über den befristeten Verzicht auf Verzugszinsen bei verspäteter Zahlung von Steuern, Lenkungsabgaben und Zollabgaben sowie Verzicht auf die Darlehensrückerstattung durch die Schweizerische Gesellschaft für Hotelkredit (20 Mar. 2020), AS 2020, 861.

${ }^{20}$ See Verordnung über den Rechtsstillstand gemäss Artikel 62 des Bundesgesetzes über Schuldbetreibung und Konkurs (18 Mar. 2020), AS 2020, 839. 
throughout Switzerland. Only two days later, on 20 March 2020, the Swiss Federal Council further ordered a temporary standstill in civil and administrative proceedings for maintaining the judicial system in times of pandemic. ${ }^{21}$ From 21 March to and including 19 April 2020, all time limits in civil and administrative proceedings have been suspended, which was also relevant for commercial contracts. This measure, which intended to provide Swiss companies relief in this area in order to avert a major wave of bankruptcies, was subsequently not prolonged but replaced by another one. On 16 April 2020, the Swiss Federal Council took additional measures to prevent bankruptcies and job losses, in particular a temporary relief from the obligation to notify over-indebtedness, which would normally lead to immediate bankruptcy, and the possibility of a temporary Covid-19 deferral, especially for small and mediumsized enterprises. ${ }^{22}$

In France, the French Government has issued a massive aid package to business enterprises that offered, among other things, loans on favourable terms or deferred payments of social security contributions and taxes. The main measures implemented by the government to help companies overcome their liquidity issues was the state guarantee scheme for new money loans. ${ }^{23}$ Under this scheme, the French Republic guaranteed the reimbursement of loans granted between 16 March and 31 December 2020 up to an aggregated amount of 300 billion euro. This scheme was managed by Bpifrance, the French state-owned investment bank, which also undertook several additional commitments aimed at ensuring that French companies did not fail to meet their financial commitments due to the coronavirus outbreak. These commitments included guarantees for small and medium-sized enterprises and intermediary companies and new loans (prêts atout, prêts rebond) for very small firms, small and medium-sized enterprises and intermediary companies. Other aid measures that are targeting the liquidity needs of small and medium-sized enterprises included repaid advances (avances remboursables) and subsidized loans (prêts à taux bonifiés). In addition, the government also set up a solidarity fund with an endowment of 7 billion euro that aimed to provide tax-free support for micro-entrepreneurs, the self-employed and liberal professions 'particularly affected by the economic, financial and social consequences' of the coronavirus pandemic. Moreover, in order to ensure that distressed companies were not forced into insolvency proceedings, the French Government decided to open collective or conciliation proceedings, suspend the duty to file

21 See Verordnung über den Stillstand der Fristen in Zivil- und Verwaltungsverfahren zur Aufrechterhaltung der Justiz im Zusammenhang mit dem Coronavirus (COVID-19) (20 Mar. 2020), AS 2020, 849.

22 See Verordnung über insolvenzrechtliche Massnahmen zur Bewältigung der Coronakrise (16 Apr. 2020), AS 2020, 1233.

${ }_{23}$ See Loi no. 2020-289 (23 Mar. 2020) de finances rectificative pour 2020, JORF 0072, no. 1 modifié par Loi no. 2020-473 (25 Apr. 2020), JORF 0102, no. 1 et Loi no. 2020-935 (30 Jul. 2020), JORF 0187, no. 1; Arrêté (23 Mar. 2020) accordant la garantie de l'Etat aux établissements de crédit et sociétés de financement en application de l'article 4 de la loi n 2020-289 du 23 mars 2020 de finances rectificative pour 2020, JORF 0072, no. 10 - modifié par Arrêté (17 Apr. 2020), JORF 0087, no. 6, Arrêté (2 May 2020), JORF 0109, no. 3 et Arrêté (6 May 2020), JORF 0112, no. 12. 
for insolvency until the date falling three months after the end of the health emergency state and grant time extensions of current proceedings and plans. ${ }^{24}$ More specifically, certain extraordinary measures directly applied to commercial contracts. For instance, the French Government suspended the effects of certain contractual remedies aimed at sanctioning non-performance that a creditor could otherwise exercise during a given period of time..$^{25}$ If the exercise period expired between 12 March and (including) 23 June 2020, such liquidated damages, penalty clauses, termination clauses or forfeiture clauses were deemed not to have come into force or effect. Other than that, the French Government also provided that contractually agreed termination periods that expired within this moratorium period were automatically extended for two months as from the date of expiration of the moratorium period. ${ }^{26}$

In Italy, the Italian Government has enacted a package of financial support measures with the purpose of helping business enterprises to survive the dramatic shortterm effects of the pandemic. One important instrument was the guarantee scheme of SACE, the Italian export credit finance agency, providing up to 200 billion euro of loan guarantees during the year 2020. ${ }^{27}$ Another important instrument for larger companies was the state guarantee for loans of Cassa Depositi e Prestiti, a state-controlled Italian credit institution. ${ }^{28}$ The central guarantee fund provided guarantees of the financial liabilities of small and medium-sized enterprises. ${ }^{29}$ In addition, small and medium-sized enterprises experiencing liquidity issues resulting from the pandemic were able to require banks, financial intermediaries and other lenders to apply standstill and postponement measures. The Italian Banking Association, supported by the government, further concluded an agreement with various professional associations to set up a large-scale moratorium on debt repayment, including mortgages and repayments of small loans and revolving lines of credits. In addition, the government provided subsidized loans to small and medium-sized enterprises to support cash flow and investments during liquidity shortages. The emergency legislation also provided measures to relieve business enterprises from obligations or procedures that could

${ }^{24}$ See Ordonnance no. 2020-341 (27 Mar. 2020) portant adaption des règles relatives aux difficultés des entreprises et des exploitations agricoles à l'urgence sanitaire et modifiant certaines dispositions de procédure pénale, JORF 0076, no. 3.

${ }^{25}$ See Art. 4 of Ordonnance no. 2020-306 (25 Mar. 2020) relative à la prorogation des délais échus pendant la période d'urgence sanitaire et à l'adaptation des procédures pendant cette même période, JORF 0074, no. 9 - modifié par Ordonnance no. 2020-427 (15 Apr. 2020), JORF 0093, no. 2.

${ }^{26}$ See Art. 5 of Ordonnance no. 2020-306 (25 Mar. 2020) relative à la prorogation des délais échus pendant la période d'urgence sanitaire et à l'adaptation des procédures pendant cette même période, JORF 0074, no. 9.

${ }^{27}$ See Art. 2 of Decreto-Legge (8 Apr. 2020) no. 23, Misure urgenti in materia di accesso al credito e di adempimenti fiscali per le imprese, di poteri speciali nei settori strategici, nonché interventi in materia di salute e lavoro, di proroga di termini amministrativi e processuali, GU 161, no. 94.

${ }^{28}$ See Art. 57 of Decreto-Legge (17 Mar. 2020) no. 18, Misure di potenziamento del Servizio sanitario nazionale e di sostegno economico per familie, lavoratori e imprese connesse all'emergenza epidemiologica da COVID-19, GU 161, no. 70.

${ }^{29}$ See Art. 13 of Decreto-Legge (8 Apr. 2020) no. 23, Misure urgenti in materia di accesso al credito e di adempimenti fiscali per le imprese, di poteri speciali nei settori strategici, nonché interventi in materia di salute e lavoro, di proroga di termini amministrativi e processuali, GU 161, no. 94. 
trigger adverse effects due to the coronavirus pandemic and related restrictions. ${ }^{30}$ This included namely a moratorium on insolvency or bankruptcy proceedings (relaxation of director duties), an analysis of the impact of the coronavirus pandemic on restructuring arrangements and composition with creditors and the postponement of the new distress and insolvency regime. In addition, deadlines applicable to administrative proceedings have been subject to suspensions during the early stages of the coronavirus pandemic. ${ }^{31}$ The Italian Government further enacted a provision, according to which compliance with government-issued containment measures shall always be considered for the purposes of excluding the debtor's liability (pursuant to Articles 1218 and 1223 of the Italian Civil Code), also with regard to the application of forfeiture or penalties related to delayed performance or non-performance. ${ }^{32}$ Specifically, this provision also and in particular applied to delays or breaches of commercial contracts.

\section{General Measures for Customers: Responses for Consumer Contracts}

The extraordinary measures for customers were largely contract-related. ${ }^{33}$ Such measures included not only a moratorium for performance and termination of long-term contracts covering basic needs and contracts relating to consumer credits, but also voucher solutions for leisure events and facilities as well as travel tickets and packages. Other measures included the standstill of procedural and/or substantive time

\footnotetext{
30 See Arts 5, 9 and 10 of Decreto-Legge (8 Apr. 2020) no. 23, Misure urgenti in materia di accesso al credito e di adempimenti fiscali per le imprese, di poteri speciali nei settori strategici, nonché interventi in materia di salute e lavoro, di proroga di termini amministrativi e processuali, GU 161, no. 94.

31 See Art. 103 of Decreto-Legge (17 Mar. 2020) no. 18, Misure di potenziamento del Servizio sanitario nazionale e di sostegno economico per familie, lavoratori e imprese connesse all'emergenza epidemiologica da COVID-19, GU 161, no. 70; Art. 37 of Decreto-Legge (8 Apr. 2020) no. 23, Misure urgenti in materia di accesso al credito e di adempimenti fiscali per le imprese, di poteri speciali nei settori strategici, nonché interventi in materia di salute e lavoro, di proroga di termini amministrativi e processuali, GU 161, no. 94.

32 See Art. 91(1) of Decreto-Legge (17 Mar. 2020) no. 18, Misure di potenziamento del Servizio sanitario nazionale e di sostegno economico per familie, lavoratori e imprese connesse all'emergenza epidemiologica da COVID-19, GU 161, no. 70.

33 For Germany, see Thomas Rüfner, Das Corona-Moratorium nach Art. 240 EGBGB 75 JuristenZeitung 443 (2020); Martin Schmidt-Kessel \& Christina Möllnitz, Coronavertragsrecht Sonderregeln für Verbraucher und Kleinstunternehmen 73 Neue Juristische Wochenschrift 1103 (2020); Christian Wolf et al., Die zivilrechtlichen Auswirkungen des Covid-19-Gesetzes - ein erster Überblick 52 Juristische Arbeitsblätter 401 (2020). For Austria, see Thomas Haghofer, COVID-19-Pandemie: Gesetzgeber schützt betroffene Kreditnehmer 8 Zeitschrift für Verbraucherrecht 84 (2020); Markus Kellner \& Fabian Liebel, Das gesetzliche COVID-19-Kreditmoratorium: Eine Analyse der gesetzlichen Stundung von Krediten nach dem 2. COVID-19-JuBG 75 Österreichische Juristen-Zeitung 629 (2020); Gunter Mayr, COVID-19: Steuerpakete in Österreich und für eine Krise 75 Betriebs-Berater 1495 (2020). For France, see Olivier Deshayes, La prorogation des délais en période de Covid-19 : quels effets sur les contrats? 196 Recueil Dalloz 831 (2020).
} 
limits, the exclusion of contractual remedies and a temporary standstill in debt collection for travel agencies, which - in fact, adversely - affected customers. Some Member States enacted an overriding provision, according to which compliance with government-issued containment measures shall always be considered when interpreting debtor's liability and contractual remedies for non-performance.

In Germany, the emergency legislation adopted by the German Parliament covered various contract-specific issues relevant for customers and consumer contracts. On 27 March 2020, parliament enacted a moratorium for performance of certain longterm contracts for consumers. ${ }^{34}$ This moratorium related to consumer contracts regarding electricity, gas and telephone and internet connections. Specifically, service providers were not allowed to terminate contracts despite non-payment by their customers in the early stages of the pandemic (that is, until 30 June 2020). At the same time, this legislation contained rules relating to the law on loans, according to which performance under consumer loan agreements were deferred if the consumer suffered a loss of income due to the coronavirus and he or she could no longer be reasonably expected to perform. ${ }^{35}$ This is arguably the case, if his or her own or a dependent's livelihood was at risk. It was also provided that the parties may deviate from this deferral of performance by modifying the contract and agreeing on partial payments, interest and repayment adjustments or debt rescheduling. On 15 May 2020, parliament opted for a voucher solution for leisure events and leisure facilities. ${ }^{36}$ In general, both the organiser of music, cultural, sports or other recreational events and the operator of such facilities are entitled to give a voucher to the holder of an admission ticket or other entitlements to participate or a right of use, if acquired before 8 March 2020. On 10 July 2020, parliament also opted for a solution based on travel vouchers. ${ }^{37}$ The tour operator may thus offer the traveller a travel voucher instead of a refund of the tour price, if either the traveller or the tour operator withdraw from a package tour contract concluded before 8 March 2020 due to the coronavirus pandemic.

In Austria, the Austrian Parliament adopted several overriding rules and regulations, which affected consumer contracts. Most importantly, a postponement of the due date of payments for consumer credit contracts was introduced by way of an

\footnotetext{
${ }^{34}$ See Art. 5 of Gesetz zur Abmilderung der Folgen der COVID-19-Pandemie im Zivil-, Insolvenzund Strafverfahrensrecht (27 Mar. 2020), BGB1 I, 569 - Art. $240 \S 1$ 1(1) of Einführungsgesetz zum Bürgerlichen Gesetzbuche.

${ }^{35}$ See Art. 5 of Gesetz zur Abmilderung der Folgen der COVID-19-Pandemie im Zivil-, Insolvenzund Strafverfahrensrecht (27 Mar. 2020), BGB1 I, 569 - Art. $240 \S 3$ of Einführungsgesetz zum Bürgerlichen Gesetzbuche.

${ }^{36}$ See Art. 1 of Gesetz zur Abmilderung der Folgen der COVID-19-Pandemie im Veranstaltungsrecht und im Recht der Europäischen Gesellschaft (SE) und der Europäischen Genossenschaft (SCE) (15 May 2020), BGBl I, 948 - Art. $240 \S 5$ of Einführungsgesetz zum Bürgerlichen Gesetzbuche.

${ }^{37}$ See Art. 1 of Gesetz zur Abmilderung der Folgen der COVID-19-Pandemie im Pauschalreisevertragsrecht und zur Sicherstellung der Funktionsfähigkeit der Kammern im Bereich der Bundesrechtsanwaltsordnung, der Bundesnotarordnung, der Wirtschaftsprüferordnung und des Steuerberatungsgesetzes während der COVID-19-Pandemie (10 Jul. 2020), BGB1 I, 1643 - Art. 240 § 6 of Einführungsgesetz zum Bürgerlichen Gesetzbuche.
} 
emergency legislation. ${ }^{38}$ Under this legislation, customers benefit from a three-month deferral of payment. Other provisions of the relevant emergency legislation related to the limitation of interest for late payments and exclusion of collection costs and the exclusion of contractual penalties. ${ }^{39}$ The interruption of time limits in civil and administrative proceedings and the suspension of substantive time limits, in particular the statute of limitations, were particularly relevant for consumer contracts. ${ }^{40}$ In addition, the Austrian Government, together with the energy industry, passed a moratorium for consumer contracts. Under this resolution, energy suppliers agreed to not switch off customers from electricity and gas if they had difficulties in paying their electricity or gas bills.

In Switzerland, the Swiss Federal Council ordered a temporary standstill in debt collection on 18 March 2020, which also applied to customers. ${ }^{41}$ From 19 March to and including 4 April 2020, no enforcement proceedings on debt collection could have been carried out against customers throughout Switzerland. Only two days later, on 20 March 2020, the Swiss Federal Council further ordered a temporary standstill in civil and administrative proceedings for maintaining the judicial system in times of pandemic. ${ }^{42}$ From 21 March to and including 19 April 2020, all time limits in civil and administrative proceedings have been suspended, which was also relevant for consumer contracts. In addition, the Swiss Federal Council ordered a temporary standstill in debt collection for travel agencies on 20 May 2020, which inversely affected customers of the travel industry, who cannot collect their claims from cancelled trips. ${ }^{43}$ From 21 May to and including 30 September 2020, no enforcement proceedings on debt collection against travel agencies could have been carried out throughout Switzerland. Consequently, this measure, which protected travel agencies and intended to ensure that travel agencies did not have to file for bankruptcy as they were waiting for reimbursement from hotels, airlines, shipping companies and other transport and accommodation companies, adversely affected the position of customers in consumer contracts.

38 See Art. 37 of 4. COVID-19-Gesetz (4 Apr. 2020), BGB1 I, no. 24 - 2 of 2. COVID-19-JustizBegleitgesetz.

39 See Art. 37 of 4. COVID-19-Gesetz (4 Apr. 2020), BGBl I, no. $24-\S \S 3$ and 4 of 2. COVID19-Justiz-Begleitgesetz.

${ }^{40}$ For civil proceedings, see Art. 21 of 2. COVID-19-Gesetz (21 Mar. 2020), BGB1 I, no. 16 $\S \S 1$ and 2 of 1. COVID-19-Justiz-Begleitgesetz; Art. 32 of 4. COVID-19-Gesetz (4 Apr. 2020), BGB1 I, no. 24 - Änderung des 1. COVID-19-Justiz-Begleitgesetzes. For administrative proceedings, see Art. 16 of 2. COVID-19-Gesetz (21 Mar. 2020), BGB1 I, no. $16-\S \S 1$ and 2 of Verwaltungsrechtliches COVID-19-Begleitgesetz; Art. 1 of 4. COVID-19-Gesetz (4 Apr. 2020), BGB1 I, no. 24 - Änderung des Verwaltungsrechtlichen COVID-19-Begleitgesetzes.

${ }^{41}$ See Verordnung über den Rechtsstillstand gemäss Artikel 62 des Bundesgesetzes über Schuldbetreibung und Konkurs (18 Mar. 2020), AS 2020, 839.

42 See Verordnung über den Stillstand der Fristen in Zivil- und Verwaltungsverfahren zur Aufrechterhaltung der Justiz im Zusammenhang mit dem Coronavirus (COVID-19) (20 Mar. 2020), AS 2020, 849 .

43 See Verordnung über den Rechtsstillstand nach Artikel 62 des Bundesgesetzes über Schuldbetreibung und Konkurs für die Reisebranche (20 May 2020), AS 2020, 1749. 
In France, the government, represented by the President of the Republic, puts a lot of faith in the idea of a Covid-19 mediator, which was supposed to settle disputes between customers and business enterprises. This is also reflected in the relevant emergency legislation, according to which the term of such mediator was automatically renewed until two months after the end of such period, if it ended during the time between 12 March and (including) 23 June 2020. ${ }^{44}$ More specifically, certain extraordinary measures directly applied to consumer contracts. For instance, the French Government suspended the effects of certain contractual remedies aimed at sanctioning non-performance that a creditor could otherwise exercise during a given period of time. ${ }^{45}$ If the exercise period expired between 12 March and (including) 23 June 2020, such liquidated damages, penalty clauses, termination clauses or forfeiture clauses were deemed not to have come into force or effect. Other than that, the French Government also provided that contractually agreed termination periods that expired within this moratorium period were automatically extended for two months as from the date of expiration of the moratorium period. ${ }^{46}$

In Italy, the government decided already early on to protect customers, in particular for travel plans that could not be implemented. On 2 March 2020, the Italian Government adopted a Decree Law, providing for reimbursement of travel tickets and travel packages. ${ }^{47}$ This Decree Law not only stipulated that obligations arising from transport and package travel contracts concluded by specified persons affected by the coronavirus pandemic were considered impossible (under Article 1463 of the Italian Civil Code), but also established a specific procedure for obtaining and making the reimbursement of the price paid under the transport or package travel contract. Under these regulations, transportation companies must refund travel tickets or issue vouchers of an equivalent amount in cases where they were unable to provide the service. This is important because the right of withdrawal provided in the Italian Consumer Code does not apply to passenger transportation contracts. On 17 March 2020, the Italian Government further extended these regulations to accommodation contracts. ${ }^{48}$ More generally, the Italian Government enacted a provision, according to which compliance with government-issued containment measures shall always be considered for the purposes of excluding the debtor's liability (pursuant to Articles

44 See Art. 3(1) of Ordonnance no. 2020-306 (25 Mar. 2020) relative à la prorogation des délais échus pendant la période d'urgence sanitaire et à l'adaptation des procédures pendant cette même période, JORF 0074, no. 9 - modifié par Ordonnance no. 2020-595 (20 May 2020), JORF 0124, no. 6.

45 See Art. 4 of Ordonnance no. 2020-306 (25 Mar. 2020) relative à la prorogation des délais échus pendant la période d'urgence sanitaire et à l'adaptation des procédures pendant cette même période, JORF 0074, no. 9 - modifié par Ordonnance no. 2020-427 (15 Apr. 2020), JORF 0093, no. 2.

46 See Art. 5 of Ordonnance no. 2020-306 (25 Mar. 2020) relative à la prorogation des délais échus pendant la période d'urgence sanitaire et à l'adaptation des procédures pendant cette même période, JORF 0074, no. 9.

${ }^{47}$ See Art. 28 of Decreto-Legge (2 Mar. 2020) no. 9, Misure urgenti di sostegno per famiglie, lavoratori e imprese connesse all'emergenza epidemiologica da COVID-19, GU 161, no. 53.

48 See Art. 88(1) of Decreto-Legge (17 Mar. 2020) no. 18, Misure di potenziamento del Servizio sanitario nazionale e di sostegno economico per familie, lavoratori e imprese connesse all'emergenza epidemiologica da COVID-19, GU 161, no. 70. 
1218 and 1223 of the Italian Civil Code), also with regard to the application of forfeiture or penalties related to delayed performance or non-performance. ${ }^{49}$ Specifically, this provision also and in particular applied to delays or breaches of consumer contracts.

\section{Specific Measures for Other Contracting Parties}

\subsection{Responses for Employment Contracts}

The extraordinary measures for employers and employees were numerous and concerned various issues. ${ }^{50}$ Interestingly, they did not only vary considerably from one

49 See Art. 91(1) of Decreto-Legge (17 Mar. 2020) no. 18, Misure di potenziamento del Servizio sanitario nazionale e di sostegno economico per familie, lavoratori e imprese connesse all'emergenza epidemiologica da COVID-19, GU 161, no. 70.

50 For Germany, see Axel Bertram et al., Arbeiten im Home Office in Zeiten von Corona Ein Leitfaden zu Home Office und mobilem Arbeiten (Munich: Beck, 2020); Philipp Fischinger, Arbeitsrechtliche Fragen in der Corona-Krise 52 Juristische Arbeitsblätter 561 (2020); Michael Fuhlrott \& Katharina Fischer, Corona: Virale Anpassungen des Arbeitsrechts 37 Neue Zeitschrift für Arbeitsrecht 345 (2020); Felix Geulen \& Volker Vogt, Kurzarbeit in der Corona Krise 12 Arbeitsrecht Aktuell 181 (2020); Klaus-Stefan Hohenstatt \& Christopher Krois, Lohnrisiko und Entgeltfortzahlung während der Corona-Pandemie 37 Neue Zeitschrift für Arbeitsrecht 413 (2020); Klaus-Stefan Hohenstatt \& Ulrich Sittard (eds.), Arbeitsrecht in Zeiten von Corona - Ein Leitfaden für Betriebe und Beschäftigte (Munich: Beck, 2020); Eberhard Kiesche \& Wolfhard Kohte, Arbeits- und Gesundheitsschutz in Zeiten von Corona - Der Leitfaden für Betriebe und Beschäftigte (Munich: Beck, 2020); Stefan Müller \& Marc Becker, Pandemiebedingte Leistungshindernisse in der Arbeitsrechtspraxis 1 COVID-19 und Recht 126 (2020); Christina Reifelsberger, Arbeitsschutz und COVID-19 - Haftung des Arbeitgebers 1 COVID-19 und Recht 357 (2020); Adam Sagan \& Marius Brockfeld, Arbeitsrecht in Zeiten der Corona-Pandemie 73 Neue Juristische Wochenschrift 1112 (2020); Fabian Schmeisser \& Magdalena Fauth, Kurzarbeit in Zeiten der Corona-Krise 1 COVID-19 und Recht 363 (2020); Bettina Schmidt (ed.), Erste Hilfe bei Kurzarbeit in Zeiten von Corona - Ein Leitfaden zu Kurzarbeit und Kurzarbeitergeld (Munich: Beck, 2020); Ulrich Tödtmann \& Eler v. Bockelmann (eds.), Arbeitsrecht in Not- und Krisenzeiten: Die Corona-Pandemie und ähnliche Krisensituationen (Munich: Beck, 2020). For Austria, see Susanne Auer-Mayer, Ausgewählte Fragen zur Kurzarbeit 55 Zeitschrift für Arbeits- und Sozialrecht 220 (2020); Wolfgang Mazal, Entgeltfortzahlung bei pandemiebedingter Einschränkung des sozialen Lebens 31 Fachzeitschrift für Wirtschaftsrecht 280 (2020); Florian Mosing, COVID-19-Kurzarbeit 4 Journal für Arbeits und Sozialrecht 141 (2020); Adalbert Spitzl, Sind Kündigungen des AG im Zuge von Kurzarbeit nichtig? 31 Fachzeitschrift für Wirtschaftsrecht 474 (2020). For Switzerland, see Alfred Blesi et al., Arbeitsrecht in COVID-19: Ein Panorama der Rechtsfragen zur Corona-Krise, 39-76 (Basel: Helbing Lichtenhahn, 2020); Thomas Geiser, Arbeitsrechtliche Regelungen im Zusammenhang mit dem Coronavirus 29 Aktuelle Juristische Praxis 545 (2020); Thomas Geiser et al., Klärung arbeitsrechtlicher Fragen im Zusammenhang mit dem Coronavirus, Jusletter (23 Mar. 2020); Jean Christophe Schwaab, Le travailleur en quarantaine, Jusletter (23 Mar. 2020); Thomas Pietruszak, Lockdown und Lohnfortzahlung, Jusletter (14 Apr. 2020); Emanuel Georg Tschannen, Das Corona-Massnahmenpaket des Bundesrats: Eine Würdigung aus arbeitsrechtlicher Perspektive, Jusletter (14 Apr. 2020); Isabelle Wildhaber, Das Arbeitsrecht in Pandemiezeiten 139 Zeitschrift für Schweizerisches Recht [Sondernummer] 157 (2020). For France, see Grégoire Duchange, Coronavirus et contrat de travail 7 Actualité Juridique Contrat 191 (2020); Yann Leroy, Le droit du travail face au Covid-19 : adaptation ou menace? 31 Droit social 577 (2020); Christophe Radé, Covid-19 et force majeure 31 Droit social 598 (2020). 
jurisdiction to the other, but also over time. The most important measure was arguably the facilitation and extension of state-sponsored short-time work programs. Under these schemes, employers reduced their employees' working hours instead of laying them off. Moreover, labour laws of many countries were amended during the early stages of the crisis, particularly with regard to the duty to pay wages, holiday arrangements and time for childcare. Other measures, which have been put in place since the reopening of the economies after a lockdown, concerned worker protection, including and in particular the protection of high-risk groups.

In Germany, performance under employment contracts was significantly affected by the state-sponsored short-time work program (Kurzarbeit), later also by the new standards and rules on work safety. On 13 March 2020, the German Parliament enacted a new law in a fast-track procedure, which considerably simplified access to this short-time work program. ${ }^{51}$ Since March 2020, firms were able to request support if 10 percent of their workforce was affected by cuts in working hours (compared to 30 percent before the crisis). According to this program, employers initially continued to pay their employees any actual hours worked plus at least 60 percent of their net earnings losses because of reduced hours (at least 67 percent for employees with children). The public employment service reimbursed employers for these payments and for 100 percent of social-insurance contributions for the lost work hours. The scope of application of this subsidy, which included workers on temporary contracts and apprentices, was further extended to agency workers at the start of the crisis. In addition, restrictions on taking another job while on short-time work have been lifted. After the lockdown, the focus shifted to work safety. ${ }^{52}$ On 16 April 2020, the administration presented the new occupational health and safety standard on Covid-19. Later, in August 2020, the administration issued the Covid-19 occupational safety rule.

In Austria, employment contracts have been affected in many ways by the emergency legislation. One example was the new provision on short-time work (Kurzarbeit). ${ }^{53}$ This provision allowed employers to reduce personnel costs and avoid terminating employment contracts while the business was affected by a coronavirusrelated shutdown or other government-imposed measures. The employer was required to compensate the employee for the time that he or she has actually worked (which must be, on average, at least 10 percent of the time originally agreed), while the rest (up to 90 percent of the original wage) was provided by the Austrian Public Employment Service. Another example was the addition of sections 1155(3) and 1155(4) of

${ }^{51}$ See Gesetz zur befristeten krisenbedingten Verbesserung der Regelungen für das Kurzarbeitergeld (13 Mar. 2020), BGB1 I, 493.

52 See SARS-CoV-2-Arbeitsschutzsstandard, Bundesministerium für Arbeit und Soziales (16 Apr. 2020); SARS-CoV-2-Arbeitsschutzregel, Arbeitsschutzausschüsse beim Bundesministerium für Arbeit und Soziales (20 Aug. 2020).

${ }^{53}$ See Arts 5 and 6 of COVID-19-Gesetz (15 Mar. 2020), BGB1 I, no. 12 - Änderungen des Arbeitsmarktpolitik-Finanzierungsgesetzes und des Arbeitsmarktservicegesetzes; Arts 4 and 5 of 2. COVID-Gesetz (21 Mar. 2020), BGB1 I, no. 16 - Änderungen des Arbeitsmarktpolitik-Finanzierungsgesetzes und des Arbeitsmarktservicegesetzes. 
the Austrian Civil Code. ${ }^{54}$ In case of a leave of absence due to a government-imposed shut-down or restriction, the employee continued to have a right to full remuneration, but the employee had to use vacation time (up to two weeks) and compensation time (combined up to eight weeks). In addition, employers and employees were able to agree on special leave for childcare purposes for the maximum period of three weeks; one third of such leave was state funded. ${ }^{55}$

In Switzerland, government and administration considerably extended and simplified short-time work (Kurzarbeit). ${ }^{56}$ In addition, the Swiss Federal Council adopted specific rules to protect high-risk groups from coronavirus diseases.$^{57}$ From 16 March until 22 June 2020, the Swiss Government required employers to allow employees who belong to a high-risk group to carry out their work from home and provide such employees with the necessary tools to perform their employment contract in their home office. If it was not possible for an employee to work from home, the employer had to find alternative work for the employee. In cases in which this was either not possible or the employee declined the alternative work proposed by the employer, the employer was supposed to give leave to the employee but continue to pay his or her salary. Since 22 June 2020, the Swiss Government provides preventive measures to protect employees in general, but not specifically for high-risk groups anymore. ${ }^{58}$

In France, the emergency legislation empowered the government to amend by ordinance the rules of labour law, in particular with regard to the implementation of a short-time work scheme (activité partiel). ${ }^{59}$ Over the past few months, the French government has used this power extensively, setting up an exceptional short-time work scheme, which has been amended and extended several times. ${ }^{60}$ By doing so,

\footnotetext{
54 See Art. 10 of 2. COVID-19-Gesetz (21 Mar. 2020), BGB1 I, no. 16 - Änderung des allgemeinen bürgerlichen Gesetzbuchs.

55 See Art. 7 of COVID-19-Gesetz (15 Mar. 2020), BGB1 I, no. 12 - Änderung des Arbeitsvertragsrechts-Anpassungsgesetzes; Art. 10 of 2. COVID-19-Gesetz (21 Mar. 2020), BGB1 I, no. 16 - Änderung des allgemeinen bürgerlichen Gesetzbuchs.

56 See Verordnung über Massnahmen bei Erwerbsausfall im Zusammenhang mit dem Coronavirus (COVID-19) (20 Mar. 2020), AS 2020, 871.

57 See Arts $10 b$ and $10 c$ of Verordnung 2 über Massnahmen zur Bekämpfung des Coronavirus (COVID-19) (13 Mar. 2020), AS 2020, 773 - Änderung (16 Mar. 2020), AS 2020, 783; Änderung (1 Apr. 2020), AS 2020, 1131; Änderung (16 Apr. 2020), AS 2020, 1249; Änderung (27 May 2020), AS $2020,1815$.

58 See Arts 10 and 11 of Verordnung über Massnahmen in der besonderen Lage zur Bekämpfung der Covid-19-Epidemie (19 Jun. 2020), AS 2020, 2213.

59 See Art. 11(I)(1)(b) of Loi no. 2020-290 (23 Mar. 2020) d'urgence pour faire face à l'épidémie de covid-19, JORF 0072, no. 2; Art. 6 of Loi no. 2020-546 (11 May 2020) prorogeant l'état d'urgence sanitaire et complétant ses dispoitions, JORF 0116, no. 1.

${ }^{60}$ See Décret no. 2020-325 (25 Mar. 2020) relatif à l'activité partielle, JORF 0074, no. 55 modifications du Code du travail; Ordonnance no. 2020-346 (27 Mar. 2020) portant mesures d'urgence en matière d'activité partielle, JORF 0076, no. 24; Arrêté (31 Mar. 2020) modifiant le contingent annuel d'heures indemnisables au titre de l'activité partielle pour l'année 2020, JORF 0081, no. 12; Art. 6 of Ordonnance no. 2020-428 (15 Apr. 2020) portant diverses dispositions sociales pour faire face à l'épidémie de covid-19, JORF 0093, no. 5; Décret no. 2020-435 (16 Apr. 2020) portant mesures d'urgence en matière d'activité partielle, JORF 0094, no. 38 - modifié par Décret no. 2020-522 (5 May 2020), JORF 0111, no. 34; Ordonnance no. 2020-460 (22 Apr. 2020) portant diverses mesures prises
} 
the government also eased employment law provisions on the modification of ongoing employment contracts. Consequently, employers were able to implement such a short-time work scheme without requiring the usual prior administrative authorization, if the activity of the business was substantially affected by the coronavirus pandemic and they have already exhausted other reasonable steps to mitigate losses. More concretely, this means that employers could, after consulting with their employees, reduce the working hours below the legal minimum, shut down part of their activity or impose technical leave by paying employees 70 percent of their gross wage for the hours they do not work, with the remainder being subsidized by the government. As a result, most employers did not bear any costs for hours not worked, as the state reimbursed what they paid to employees up to a cap of 4.5 times the hourly minimum wage. After many French businesses had to close their doors for some time in the early stages of the pandemic, the government reopened its economy over the summer months and issued guidelines protecting the health of workers and enabling the continuity of economic activity. ${ }^{61}$

In Italy, the government took various measures in the area of labour law, which applied to employers and employees. In March 2020, the Italian Government made available additional public schemes to handle the coronavirus pandemic in this area. Most notably, the Italian Government extended the reach of its short-time work scheme (cassa integrazione guadagni) by allowing firms of any size and from all sectors to apply. ${ }^{62}$ According to this scheme, firms had to declare that they have been negatively affected by the current crisis without having to provide detailed evidence. While employers' participation in the cost of the scheme has been suspended, benefit levels for workers have remained unchanged. In addition, the Italian Government

pour faire face à l'epidémie de covid-19, JORF 0099, no. 15 - modifié par Décret no. 2020-509 (2 May 2020), JORF 0108, no. 21; Décret no. 2020-794 (26 Jun. 2020) relatif à l'activité partielle, JORF 0159, no. 35; Décret no. 2020-926 (28 Jul. 2020) relatif au dispositif spécifique d'activité partielle en cas de réduction d'activité durable, JORF 0186, no. 37.

${ }^{61}$ See Ordonnance no. 2020-322 (25 Mar. 2020) adaptant temporairement les conditions et modalités d'attribution de l'indemnité complémentaire prévue à l'article L. 1226-1 du code du travail et modifiant, à titre exceptionnel, les dates limites et les modalités de versement des sommes versées au titre de l'intéressement et de la participation, JORF 0074, no. 50; Ordonnance no. 2020-323 (25 Mar. 2020) portant mesures d'urgence en matière de congés payés, de durée du travail et de jours de repos, JORF 0074, no. 52; Ordonnance no. 2020-324 (25 Mar. 2020) portant mesures d'urgence en matière de revenus de remplacement mentionnés à l'article L. 5421-2 du code du travail, JORF 0074, no. 54; Ordonnance no. 2020-385 (1 Apr. 2020) modifiant la date limite et les conditions de versement de la prime exceptionnelle de pouvoir d'achat, JORF 0080, no. 17; Décret no. 2020-471 (24 Apr. 2020) portant dérogation au principe de suspension des délais pendant la période d'état d'urgence sanitaire liée à l'épidémie de covid-19 dans le domaine du travail et de l'emploi, JORF 0101, no. 10; Décret no. 2020-482 (27 Apr. 2020) relatif à la prorogation exceptionnelle des délais de formation obligatiore des conseillers prud'hommes et des juges des tribunaux de commerce, JORF 0104, no. 1.

62 See Arts 19 to 22 of Decreto-Legge (17 Mar. 2020) no. 18, Misure di potenziamento del Servizio sanitario nazionale e di sostegno economico per familie, lavoratori e imprese connesse all'emergenza epidemiologica da COVID-19, GU 161, no. 70. 
provided for a reduction in working hours and leave. ${ }^{63}$ These measures related to leave and indemnity of employees in the private sector, an extension of paid leave as well as leave and allowances for public sector employees, including bonuses for the purchase of baby-sitting services for employees in the public and private health sector. Additional measures consisted of allowances for self-employed workers, an extension of the time limits for unemployment claims, an extension of deadlines related to social security and welfare benefits, social security contributions and compulsory insurance premiums as well as a suspension of the time limit for appealing dismissals. ${ }^{64}$ In May 2020, the Italian Government adopted various policy measures in relation to income support, parental leave, rest and holiday leave, agile working (teleworking) and dismissal. ${ }^{65}$ In addition, the Italian Parliament adopted special provisions arranged by social partners and the legislator to preserve both health and safety of employees and to prevent the spread of the coronavirus at the workplace. ${ }^{66}$

63 See Arts 23 to 26 of Decreto-Legge (17 Mar. 2020) no. 18, Misure di potenziamento del Servizio sanitario nazionale e di sostegno economico per familie, lavoratori e imprese connesse all'emergenza epidemiologica da COVID-19, GU 161, no. 70.

${ }^{64}$ See Arts 27, 28, 33, 34, 37 and 46 of Decreto-Legge (17 Mar. 2020) no. 18, Misure di potenziamento del Servizio sanitario nazionale e di sostegno economico per familie, lavoratori e imprese connesse all'emergenza epidemiologica da COVID-19, GU 161, no. 70.

${ }^{65}$ For income support, see Arts 68, 70,84 and 93 of Decreto-Legge (17 Mar. 2020) no. 18, Misure di potenziamento del Servizio sanitario nazionale e di sostegno economico per familie, lavoratori e imprese connesse all'emergenza epidemiologica da COVID-19, GU 161, no. 70. For parental leave, see Art. 73 of Decreto-Legge (17 Mar. 2020) no. 18, Misure di potenziamento del Servizio sanitario nazionale e di sostegno economico per familie, lavoratori e imprese connesse all'emergenza epidemiologica da COVID-19, GU 161, no. 70. For temporary dismissal ban, see Art. 80 of Decreto-Legge (17 Mar. 2020) no. 18, Misure di potenziamento del Servizio sanitario nazionale e di sostegno economico per familie, lavoratori e imprese connesse all'emergenza epidemiologica da COVID-19, GU 161, no. 70. For agile working, see Art. 90 of Decreto-Legge (17 Mar. 2020) no. 18, Misure di potenziamento del Servizio sanitario nazionale e di sostegno economico per familie, lavoratori e imprese connesse all'emergenza epidemiologica da COVID-19, GU 161, no. 70.

${ }^{66}$ See Protocollo condiviso di regolamentazione delle misure per il contrasto e il contenimento della diffusione del virus Covid-19 negli ambienti di lavoro (14 Mar. 2020); Decreto del Presidente del Consiglio dei Ministri (22 Mar. 2020), Ulteriori disposizioni attuative del decreto-legge 23 febbraio 2020 , n. 6 , recante misure urgenti in materia di contenimento e gestione dell'emergenza epidemiologica da COVID-19, applicabili sull'intero territorio nazionale, GU 161, no. 76; Decreto-Legge (25 Mar. 2020) no. 19, Misure urgenti per fronteggiare l'emergenza epidemiologica da COVID-19, GU 161, no. 79. See also Protocollo condiviso di regolamentazione delle misure per il contrasto e il contenimento della diffusione del virus Covid-19 negli ambienti di lavoro (24 Apr. 2020); Decreto del Presidente del Consiglio dei Ministri (26 Apr. 2020), Ulteriori disposizioni attuative del decreto-legge 23 febbraio 2020, n. 6, recante misure urgenti in materia di contenimento e gestione dell'emergenza epidemiologica da COVID-19, applicabili sull'intero territorio nazionale, GU 161, no. 108. 


\subsection{Responses for Lease Contracts}

The extraordinary measures for lessors and lessees varied greatly from jurisdiction to jurisdiction. ${ }^{67}$ The most common were rules and regulations concerning a moratorium prohibiting the termination of such contracts, if rent payments were delayed. The biggest bone of contention, which the countries have solved very differently so far, concerned rent for commercial premises, especially during a lockdown period.

${ }^{67}$ For Germany, see Markus Artz \& Elmar Steyl, Mietrecht in Hubert Schmidt, COVID-19: Rechtsfragen zur Corona-Krise, 55-94 (2nd ed., Munich: Beck, 2020), at § 3 paras 1-105; Martin Häublein \& Maximilian Müller, Wer trägt das Pandemierisiko in der Geschäftsraummiete? Zur Mietzahlungspflicht bei pandemiebedingten Geschäftsschliessungen und anderen Betriebsbeeinträchtigungen 23 Neue Zeitschrift für Miet- und Wohnungsrecht 481 (2020); Julius Hellmich, Vollständige Miete bei vollständigem Verlust der Nutzbarkeit? Die Untersagung des Publikumsverkehrs als Mangel im Sinne von $\$ 536$ Abs. 1 S. 1 BGB 1 COVID-19 und Recht 189 (2020); Jan Hellner, Pacta sunt servandagilt dieser Grundsatz auch für die Miete in Zeiten der COVID-Pandemie? Oder: Annäherung an den Begriff des mietvertraglichen Verwendungsrisikos 20 Neue Juristische Online-Zeitschrift 769 (2020); Alexander Schall, Corona-Krise: Unmöglichkeit und Wegfall der Geschäftsgrundlage bei gewerblichen Miet- und Pachtverträgen 75 JuristenZeitung 388 (2020); Christoph U. Schmid, Corona und Mietrecht in Deutschland: Insbesondere zur Verpflichtung des Gewerberaummieters zur Zinszahlung nach behördlichen Schliessungsanordnungen 61 Zeitschrift für Europarecht, Internationales Privatrecht und Rechtsvergleichung 113 (2020); Silvio Sittner, Mietrechtspraxis unter Covid-19 73 Neue Juristische Wochenschrift 1169 (2020); Cara Warmuth, $\S 313$ BGB in Zeiten der Corona-Krise - am Beispiel der Gewerberaummiete 1 COVID-19 und Recht 16 (2020); Christopher Weidt \& Anne-Colleen Schiewek, Geschäftsschliessungen wegen Corona - mietrechtlich ein Fall des § 313 BGB? 20 Neue Juristische Online-Zeitschrift 481 (2020); Kai Zehelein (ed.), COVID-19: Miete in Zeiten von Corona (Munich: Beck, 2020). For Austria, see Clara Hochleitner, Die Auswirkungen von COVID-19 auf Geschäftsraummieter und Pächter: Ist die Rechtslage tatsächlich so eindeutig? 75 Österreichische Juristen-Zeitung 533 (2020); Mark Krenn \& Angelika Schüssler-Datler, Sonderregelungen für Mietverhältnisse in der Corona-Krise: Mietrechtsänderungen durch das 2. COVID-19-Justiz-Begleitgesetz 75 Österreichische Juristen-Zeitung 581 (2020); Simon Laimer \& Martina Schickmair, Ausgewählte zivilrechtliche Probleme in der COVID19-Krise in Reinhard Resch (ed.), Das Corona-Handbuch: Österreichs Rechtspraxis zur aktuellen Lage, 253-280 (Vienna: Manz, 2020), at ch. 11 paras 3-19; Helmut Ofner, Mietrecht und die COVID-19Pandemie in Österreich: Kündigungsschutz, Mietzinsminderung, Fixkostenersatz 61 Zeitschrift für Europarecht, Internationales Privatrecht und Rechtsvergleichung 107 (2020). For Switzerland, see Andrea Haefeli et al., Coronavirus SARS-CoV-2: Klärung mietrechtlicher Fragen, Jusletter (14 Apr. 2020); Thomas Koller, Corona-Krise und Mietrecht - Rechtsöffnungsrichter in der Verantwortung, Jusletter (4 May 2020); David Lachat \& Sarah Brutschin, Die Mieten in Zeiten des Coronavirus 35 Zeitschrift für schweizerisches Mietrecht 99 (2020); David Lachat \& Sarah Brutschin, Le bail aux temps du coronavirus 142 La Semaine Judicaire 111 (2020); Jürg P. Müller, Der 'Lockdown' als Herausforderung für die Vertragsparteien bei der Miete und Pacht von Wohn- und Geschäftsräumen - eine Auslegeordnung in COVID-19: Ein Panorama der Rechtsfragen zur Corona-Krise, 77-122 (Basel: Helbing Lichtenhahn, 2020); Stephan Wolf \& Yannick Minnig, COVID-19 und Mietrecht: Zur Rechtslage in der Schweiz 61 Zeitschrift für Europarecht, Internationales Privatrecht und Rechtsvergleichung 119 (2020). For France, see Jean-Pierre Blatter, Le bail, le covid-19 et le schizophrène 31 Actualité Juridique Droit Immobilier 245 (2020); Fabien Kendérian, Le droit civil des contrats et le bail commercial en temps de crise : l'exemple de la Covid-19 41 Revue trimestrielle de droit commercial et de droit économique 265 (2020); Sébastien Regnault, Covid-19 et bail commercial 7 Actualité Juridique Contrat 193 (2020). For Italy, see Tereza Pertot, Mietrecht in Zeiten des Coronavirus: italienische Perspektive 61 Zeitschrift für Europarecht, Internationales Privatrecht und Rechtsvergleichung 131 (2020). 
In Germany, the emergency legislation adopted by the German Parliament on 27 March 2020 included certain restrictions on the termination of leases and usufructuary leases. ${ }^{68}$ According to this moratorium, landlords were prohibited from terminating a lease contract, if tenants were not able to pay rent due to the coronavirus pandemic during the months of April to June 2020. The link between the coronavirus pandemic and non-payment had to be substantiated, other termination rights remained unaffected. This moratorium apparently applied to the lease of both residential premises and commercial premises.

In Austria, the emergency legislation in particular limited the legal consequences of a default in payment with regard to residential leases. ${ }^{69}$ If the tenant of a flat was not able to pay his or her rent due in the period from 1 April to 30 June 2020 because of significantly impaired economic capacity due to the coronavirus pandemic, the landlord may not terminate the contract or demand its cancellation under Article 1118 of the Austrian Civil Code because of such default. In addition, the landlord may not claim the amount of such late payments in court until 31 December 2020 or cover them from a deposit handed over by the tenant. These rules, which remain in force until 30 June 2022, are applicable to residential premises. There is - at least so far, despite intense discussions - no emergency legislation on commercial premises in Austria. The Austrian Administration has also taken the view that the existing law already provides a solution for this, holding the landlord responsible for extraordinary coincidences. $^{70}$

In Switzerland, the Swiss Federal Council initially only took a few measures specific to lease contracts. ${ }^{71}$ First, the government determined that relocations were permitted, stating that the recommendations of the Swiss Federal Office of Public Health must be observed. Second, the government extended the deadline for payment arrears of the tenant from 30 days today to at least 90 days. This measure applied to payment arrears arising in connection with coronavirus-related government measures and to rent and ancillary costs due between 13 March and 31 May 2020. Third, the government extended the notice period for furnished rooms and parking spaces pursuant to Article $266 e$ of the Swiss Code of Obligations from two weeks to 30 days. The Swiss Government did initially not release any order in relation to commercial leases. A later proposal, however, wanted to hold commercial tenants liable for 40 percent of the agreed rent during a lockdown period, with landlords being liable for the

68 See Art. 5 of Gesetz zur Abmilderung der Folgen der COVID-19-Pandemie im Zivil-, Insolvenzund Strafverfahrensrecht (27 Mar. 2020), BGB1 I, 569 - Art. $240 \S 2$ of Einführungsgesetz zum Bürgerlichen Gesetzbuche.

${ }_{69}$ See Art. 37 of 4. COVID-19-Gesetz (4 Apr. 2020), BGBl I, no. $24-\S 1$ of 2. COVID-19-JustizBegleitgesetz.

70 See Frequently asked Questions on Corona and Justice, Austrian Federal Ministry of Justice (15 Sep. 2020), https://www.justiz.gv.at/home/covid-19/haeufige-fragen 7bd.de.html.

${ }^{71}$ See Verordnung über die Abfederung der Auswirkungen des Coronavirus im Miet- und Pachtwesen (27 Mar. 2020), AS 2020, 1099. 
remaining 60 percent. ${ }^{72}$ This deal was only applicable to commercial premises directly affected by a lockdown and to monthly rents up to an amount of 20,000 Swiss Francs. In the end, however, this proposal was not implemented, as it was finally rejected by both chambers of the Swiss Parliament on 30 November 2020 and 2 December 2020, respectively.

In France, the government adopted an Ordinance and a Decree on the treatment of commercial premises during the coronavirus pandemic. ${ }^{73}$ However, similar rules should apply to lease contracts for residential premises. ${ }^{74}$ According to these rules and regulations, the non-payment of rent and rental charges for commercial premises becoming due between 12 March 2020 and the expiry of a two months period after the end of the state of health emergency (initially planned to be 24 March 2020, then extended until 11 July 2020) could not be subject to certain contractual remedies. These remedies included financial penalties or interest for late payments, damages, liquidated damages, the enforcement of penalty clauses, termination clauses or forfeiture clauses and the activation of guarantees or sureties. In addition, all lessees exercising an economic activity were allowed to suspend the payment of rent and water, gas and electricity utility bills from 12 March 2020 until the end date of the state of emergency (that is, 11 July 2020). As a result, delays in the payment of rent or bills covered by said period could not be sanctioned, which in fact constitutes a limitation of contractual rights of such lessors. This is important because French courts - due to the fungible nature of monetary obligations - typically do not release a lessee from its obligation to pay rent based on force majeure.

In Italy, the emergency legislation did not provide any moratorium on rent payments but contained many specific and sectorial norms suspending judicial proceedings and tax deadlines and postponing mortgage payments. In March 2020, the Italian Government provided for a tax credit for retail tenants of 60 percent of the amount of the rent paid in the month of March $2020 .{ }^{75}$ This specific tax credit, however, only applied to the lease of specific properties such as shops and artisans' workshops, with

72 See Bericht über die Ergebnisse der Vernehmlassung zum Bundesgesetz über den Miet- und den Pachtzins während Betriebsschliessungen und Einschränkungen zur Bekämpfung des Coronavirus (Covid-19) (17 Sep. 2020); Botschaft zum Bundesgesetz über den Miet- und Pachtzins während Betriebsschliessungen und Einschränkungen zur Bekämpfung des Coronavirus (Covid-19) (18 Sep. 2020); draft of Bundesgesetz über den Miet- und den Pachtzins während Betriebsschliessungen und Einschränkungen zur Bekämpfung des Coronavirus (Covid-19).

73 See Arts 4(1) and 4(2) of Ordonnance no. 2020-316 (25 Mar. 2020) relative au paiement des loyers, des factures d'eau, de gaz et d'électricité afférents aux locaux professionnels des entreprises dont l'activité est affectée par la propagation de l'épidémie de covid-19, JORF 0074, no. 37; Décret no. 2020-378 (31 Mar. 2020) relatif au paiement des loyers, des factures d'eau, de gaz et d'électricité afférents aux locaux professionnels des entreprises dont l'activité est affectée par la propagation de l'épidémie de covid-19, JORF 0079, no. 26.

${ }^{74}$ See Arts 4 and 5 of Ordonnance no. 2020-306 (25 Mar. 2020) relative à la prorogation des délais échus pendant la période d'urgence sanitaire et à l'adaptation des procédures pendant cette même période, JORF 0074, no. 9 - modifié par Ordonnance no. 2020-427 (15 Apr. 2020), JORF 0093, no. 2.

75 See Art. 65 of Decreto-Legge (17 Mar. 2020) no. 18, Misure di potenziamento del Servizio sanitario nazionale e di sostegno economico per familie, lavoratori e imprese connesse all'emergenza epidemiologica da COVID-19, GU 161, no. 70. 
the exclusion of the commercial activities that were not suspended by the emergency legislation. In May 2020, the Italian Government extended the scope of application of its tax credit to other tenants, which were renting real estate for industrial, commercial, artisanal, agricultural, professional and tourist activities. ${ }^{76}$

\section{Conclusions}

This paper provides for an analysis and discussion of various extraordinary measures taken by European governments, which are related to contracts facing coronavirusrelated impediments and aim to cure the economic consequences of the coronavirus pandemic, and puts these measures into perspective. In this paper, it is generally understood that contracts may be affected either directly or indirectly during the coronavirus pandemic. This idea does not only apply to containment measures in connection with a lockdown period, but also to protection and support measures in the course of a reopening of the economy. Based on this understanding, all contracts, especially permanent contracts, are at the same time directly affected by overriding provisions, if applicable, and indirectly through other measures, from which the respective contracting parties may benefit in one form or another. From an institutional economics perspective, the main issue with this architecture is that the same problems are regulated at different levels and for different actors, which may inevitably lead to an overlap of various protection and support measures. As a result, contracting parties such as business enterprises or customers may in some cases be better off during the crisis than they would be without such a crisis. For that reason, the concept of extraordinary measures, which relates to contracts and contractual performance in times of pandemic, must be understood broadly and should also include government-induced changes in the financial position of a contracting party. An analysis and discussion of commercial and consumer contracts in general and employment and lease contracts in particular may serve as a basis for answering the underlying question of this paper on how contract law should respond to the current crisis.

Business enterprises are not only parties to commercial contracts, but also to employment contracts (as employer) and to lease contracts (either as lessor or as lessee). An analysis and discussion of commercial contracts clearly reflects policy makers' main concern to preserve contractual relations in the near term. In the longer term, however, legal systems should rather facilitate significant adjustment of contractual relations. For instance, a company's supply relations need to be changed in due course, if demand contracts for its production. Therefore, policy makers should also cope with this issue by codifying legal institutions on adaption or termination of contractual obligations. The main reason for a codification of such institutions is that

76 See Art. 28 of Decreto-Legge (19 May 2020) no. 34, Misure urgenti in materia di salute, sostegno al lovoro e all'economia, nonche' di politiche sociali connesse all'emergenza epidemiologica da COVID-19, GU 161, no. 128. 
adaption and termination of contracts will most likely become more important in the near future and quality of judicial decisions would certainly benefit from clear requirements and consequences. Such a legislative intervention can provide transaction-cost efficiency and orderliness. In addition, the careful observer will notice that not only procedural measures are involved here, but also substantive ones, namely those that lead to greater redistribution of financial resources that some of us would like to see. It is particularly striking that many companies not only benefit from favourable loans, guarantees and other securities as well as government grants and subsidies, but are also compensated by the state as employer for work not performed by their employees. These measures are important, there is no doubt about that, but at the same time one must not ignore the effects they have on contractual performance. Therefore, a company cannot discharge its contractual obligations after the state has already assumed most of its business risk. The consequence of this must be that companies should not be able to release themselves from their obligations under a contract as easily as it would perhaps be the case, if all these relationships and dependencies were to be ignored. This is of course not the case for a company that does not make use of state aid packages. It is thus particularly interesting from a legal theory perspective that pandemic support measures have a certain spill-over effect on contract law.

Customers are not only parties to consumer contracts, but also to employment contracts (as employee) and to lease contracts (either as lessor or as lessee). An analysis and discussion of consumer contracts indicates that a distinction should be made between debt contracts such as consumer credit and other types of consumption such as utilities. As debt contracts can unduly restrict the economic progress of an individual, such contracts should not be enforced excessively in times of pandemic. Other types of consumption lack this systemic element and, therefore, such contracts should - as a rule of thumb - be performed as agreed. Therefore, contract law must address both of these issues through a combination of preservation and disruption measures. In addition, the similarities of consumers with employees and lessees cannot be denied. It is therefore not surprising that the thrust of the measures adopted in all these areas is largely identical. In this regard, it is clear for once that the protection of all these individuals is achieved primarily through procedural measures and only occasionally through measures of substantive nature. This approach is clearly preferable, even if there are still frictional surfaces at one or the other interface. However, the impact of these support measures must also be taken into account in case of nonperformance of contractual obligations, which again speaks against an excuse of performance.

Other contracting parties include in particular employer and employee on the one hand and lessor and lessee on the other hand. While many European governments and their administrations have been quite generous on protecting employers and employees, lessors and lessees have - at least so far - received less attention. An analysis and discussion of responses for employment contracts suggests that pandemic support measures again aim for a preservation against excessive disruption, but there would likely be longer-term changes to workplaces and work patterns. In some sense, the coronavirus pandemic caused the future of work ('new work'), consisting of remote 
work, flexible hours and technology-enabled tools, to arrive earlier than expected. Depending on how fast things develop over the coming months and years, it will probably be necessary to amend labour laws to these circumstances. For instance, the pandemic raises questions of compensation for home office work such as the assumption of part of the cost of renting a flat or the deduction of taxes for the study. Moreover, the employer must also record working time or monitor health and safety in such a setting, which likewise causes legal issues. However, the situation with regard to rent payments, in particular for commercial premises, has meanwhile changed a bit. An analysis and discussion of responses for lease contracts also suggests that pandemic support measures aim for a preservation against excessive disruption. In the dispute over commercial leases, however, it has been proven that most lessors and lessees had found an agreement among themselves. This situation makes any intervention by the legislator unnecessary, especially since the most controversial cases arguably found their way to a judge, who is - without any doubt, at least in general - better equipped than the legislator to resolve these and all related issues.

Consequently, the question of how contract law should respond to the current crisis must be answered in a differentiated manner. It is fair to say that the contract law response to the current crisis must vary over time and also differ between various types of contracts. For commercial contracts, preservation against excessive disruption in the near term should come first, followed by a facilitation for significant adjustment in the longer term. With regard to consumer contracts, a distinction must be made between debt contracts and other types of consumption. While the former are open to government intervention, the latter are arguably not. Both lease and employment contracts pose particular problems, which arise from the nature - that is, underlying policies of social protection - of these contracts. At first glance, it seems quite obvious to summarise these situations under the same heading. On a closer look, however, important differences emerge that need to be considered. The preservation of employment contracts is necessary in order to secure the income of large parts of the population. Nevertheless, it is important to recognise when such measures should cease because the patient can meanwhile stand on his or her own feet. The situation is different with regard to lease contracts. Renting an apartment is not a commodity that is essential for the functioning of the economy, at least not to the same extent as a continuous inflow of income. As most contracting parties have meanwhile reached an agreement among themselves on how to allocate the risk during a lockdown, it is certainly wise for the legislator to stay out of it. 
